\title{
Effects of osmotic shock on production of $\beta$-carotene and glycerol in a naturally isolated strain of Dunaliella salina
}

\author{
Nima Montazeri-Najafabady ${ }^{1}$, Manica Negahdaripour ${ }^{1}$, Mohammad Hossein Salehi ${ }^{1}$, Mohammad Hossein Morowvat ${ }^{2}$, \\ Saeedeh Shaker ${ }^{2}$, Younes Ghasemi ${ }^{1,2^{*}}$ \\ ${ }^{1}$ Department of Pharmaceutical Biotechnology, School of Pharmacy, Shiraz University of Medical Sciences, P.O. Box 71468-64685, Shiraz, Iran. \\ ${ }^{2}$ Pharmaceutical Sciences Research Center, School of Pharmacy, Shiraz University of Medical Sciences, P.O. Box 71345-158, Shiraz, Iran.
}

\begin{tabular}{l} 
ARTICLE INFO \\
\hline Article history: \\
Received on: $21 / 05 / 2016$ \\
Revised on: $23 / 06 / 2016$ \\
Accepted on: $14 / 07 / 2016$ \\
Available online: $30 / 08 / 2016$ \\
\hline Key words: \\
Glycerol, $\beta$-carotene, \\
Osmotic shock, Dunaliella \\
salina, Functional food.
\end{tabular}

\begin{abstract}
In the present study, the effects of hypo-osmotic and hyper-osmotic shock on $\beta$-carotene and glycerol production by a native strain of Dunaliella salina isolated from Maharlu Salt Lake, Fars province, Iran, were investigated. The amount of $\beta$-carotene and glycerol at $1 \mathrm{~h}, 2 \mathrm{~h}, 8 \mathrm{~h}$ and $24 \mathrm{~h}$ after initiating hypo-osmotic $(1 \mathrm{M}$ $\mathrm{NaCl})$ and hyper-osmotic shocks $(3 \mathrm{M} \mathrm{NaCl})$; and at normal condition $(2 \mathrm{M} \mathrm{NaCl})$ were measured. At hyperosmotic medium, $\beta$-carotene concentration reached to maximum amount after $2 \mathrm{~h}$ and remained constant up to $24 \mathrm{~h}$. Even so, increasing of glycerol concentration was initiated after $2 \mathrm{~h}$ and reached the highest value at $24 \mathrm{~h}$ after salinity stress induction. At hypo-osmotic shock, $\beta$-carotene and glycerol concentrations were decreased. There are lots of lakes and salt marshes in Iran, which can be suitable environments for growing $D$. salina. So it seems that the isolated $D$. salina is potentially useful for planting in small locations to promote the commercial production of $\beta$-carotene and glycerol.
\end{abstract}

\section{INTRODUCTION}

Microalgae have already served as a major natural producer of valuable macromolecules including carotenoids, fatty acids (omega-3), biofuel, and single cell protein; and also bioconverter of steroids (Ghasemi et al., 2011a; Ghasemi et al., 2008a; Nasseri et al., 2011; Yazdi et al., 2005). Dunaliella salina is a halo-tolerant, motile, bi-flagellated green marine micro alga that can produce high-value compounds during extreme environmental conditions, such as high light intensity, nutrient deprivation, low temperature, and high salt concentrations (Besson and Guiraud, 2013; Lee et al., 2014; Saha et al., 2013). Recently, D. Salina has received considerable attention through its ability to survive under a wide range of salinity environments

\footnotetext{
* Corresponding Author

Younes Ghasemi, Pharmaceutical Sciences Research Center, School of Pharmacy, Shiraz University of Medical Sciences, P.O. Box 71345-158, Shiraz,Iran.Email: ghasemiy@sums.ac.ir
}

(0.05 to $5.5 \mathrm{M} \mathrm{NaCl}$ ) (Mishra and Jha, 2009 and Mojaat et al., 2008). When D. Salina cells are exposed to high concentrations of salt, due to the existing osmotic pressure, structural and biochemical changes happen within cells to maintain a relatively low intracellular sodium concentration (Chen et al., 2011). One of the major changes that occur inside D. Salina cells at the time of osmotic stress is de novo synthesis of glycerol, which gives $D$. Salina a unique ability for studying the mechanism of osmoregulation (Chen et al., 2012). Increasing $\mathrm{NaCl}$ concentrations from $1 \mathrm{M}$ to $3 \mathrm{M}$ will result in changing the glycerol content and reaching to its maximum level after $24 \mathrm{~h}$ (Zhao et al., 2013). Glycerol is a chemical substance with different applications in food, chemical and pharmaceutical industries (e.g. as vehicle, sweetening agent, emollient, and humectant). It can also be used as a raw material for new chemical and biochemical processes (Chow et al., 2013, De Santos Silva and Ferreira, 2012 and Yuan and Li, 2012). Currently, the first-generation trans-esterification reactions in the biodiesel or soap industries is the main chemical procedure for production of glycerol (Xiao et al., 2013). 
However, there is a need to assign a new glycerol production process, which does not fluctuate with the trends in biodiesel production or the supply of vegetable oil, which most biodiesel processes depend on it. Although, glycerol may be produced by certain bacteria, yeasts or fungi, this process has many disadvantages such as requiring an organic carbon source, higher material costs, and downstream recovery complexities (Wang et al., 2001).

D. Salina is one of the glycerol natural sources and cells prepared glycerol by two different metabolic pathways. One is photosynthetic fixation of carbon dioxide, and the other is the starch conversion (Chen et al., 2011 and Chow et al., 2013). Dunaliella can accumulate glycerol up to 50\% of dry weight under appropriate conditions (Hosseini Tafreshi and Shariati, 2009).

$\beta$-carotene is another molecule that can be accumulated as lipid globules in the inter thylakoid space of the chloroplasts in Dunaliella under salinity stress (Saha et al., 2013). Many studies have reported that under stress conditions, Dunaliella species may accumulate $\beta$-carotene up to $10 \%$ of a dry weight biomass (Lamers et al., 2012).Recently, due to its demand in pharmaceutical and food industries, production of $\beta$-carotene has attracted more attention (Mojaat et al., 2008).

To our best knowledge, there is a few works on production of glycerol and $\beta$-carotene by native strains of $D$. salina in geographically distinct of Iran.In the present study, the effects of salinity on glycerol and $\beta$-carotene produced by a native strain of D. salina, isolated from Maharlu Salt Lake, Fars province, Iran, was investigated.

\section{MATERIALS AND METHODS}

\section{Organisms and culture conditions}

D. salina was isolated from the water samples, collected from Maharlu Salt Lake, located $30 \mathrm{~km}$ southeast of Shiraz, Iran. Single colonies were derived from individual cells by repeated subculturing on agar plates as described elsewhere (Lers et al., 1990 and Powtongsook et al., 1995). Each colony was transferred to a liquid nutrient medium. Purified D. salina (MCCS 001) was cultured in modified Johnson medium (Anderson et al., 2005).

\section{Identification of Microalgae}

Identification of the isolated microalgae was done using morphological studies and taxonomical approaches as described before (Ghasemi et al., 2007 and Rasoul-Amini et al., 2010). The 18S rRNA gene sequence of Dunaliella salina was amplified using two sets of primers. The applied PCR condition has been described before (Ghasemi et al., 2011b and Ghasemi et al., $2008 \mathrm{~b})$. The PCR products were electrophoresed in a $1 \%(\mathrm{w} / \mathrm{v})$ agarose gel. The sequence was determined by the CinnaGen Company with the primers.

\section{Cell counting}

For counting the microalgal cells, each time $1 \mathrm{~mL}$ of algal suspension was removed through sampling tube and then direct count was performed using Neubauer haemocytometer and a light microscope.

\section{$\beta$-carotene extraction and assay}

$\beta$-carotene was extracted using the $n$-hexane method (Rodriguez, 2001). After exposing the cell to salinity stress (1 h, 2 $\mathrm{h}, 8 \mathrm{~h}$ and $24 \mathrm{~h}$ ), $1 \mathrm{~mL}$ of the micro-algal suspension was taken and centrifuged at $3000 \mathrm{rpm}$ at $4^{\circ} \mathrm{C}$ for $5 \mathrm{~min}$ and then rinsed with ethanol/n-hexane (2/1) and distilled water, respectively, and analyzed with $\mathrm{n}$-hexane method. $\beta$-carotene concentration was determined by colorimetric assay. $\beta$-carotene content was measured at $450 \mathrm{~nm}$ using a UV/Visible spectrophotometer (PG instrument Ltd.).

The amount of $\beta$-carotene extracted in $n$-hexane was determined spectrophotometrically (Eijckelhoff and Dekker, 1997)using the following Eq.1

(Eq. 1)

$$
ß-\text { carotene }(\mu \mathrm{g} / \mathrm{mL})=25.2 \times \mathrm{A} 450
$$

\section{Osmotic shock and glycerol determination}

The microalga was grown under $2 \mathrm{M} \mathrm{NaCl}$. When the cell number reached about $1 \times 10^{6}$ cell $/ \mathrm{mL}$, the cells were transferred to a medium containing 1 and $3 \mathrm{M} \mathrm{NaCl}$, to investigate the effect of osmotic shock on the glycerol content. The amount of glycerol at $0,1,2,8$ and $24 \mathrm{~h}$ after initiating salt stress was measured using a spectrophotometric method.

For quantifying the glycerol concentration, $1 \mathrm{~mL}$ of culture was mixed with $300 \mu \mathrm{L}$ sterile water and $400 \mu \mathrm{L}$ chloroform. The sample tubes were centrifuged at $6797 \mathrm{~g}$ for 20 min at $25{ }^{\circ} \mathrm{C} .30 \mu \mathrm{L}$ of sterile water and $400 \mu \mathrm{L}$ of sodium periodate reagent $(65 \mathrm{mg} \mathrm{NaIO}$ in $90 \mathrm{~mL}$ of water, $10 \mathrm{~mL}$ acetic acid, and $7.7 \mathrm{~g}$ ammonium acetate) was added to $30 \mu \mathrm{L}$ of the supernatant. The mixture was incubated at room temperature for 5 min. After that, $600 \mu \mathrm{L}$ of acetyl acetone reagent (acetyl acetone/isopropanol (99/1)) was added. Then samples were incubated at $60^{\circ} \mathrm{C}$ for $30 \mathrm{~min}$. Glycerol concentration was calculated by spectrophotometric absorption at $410 \mathrm{~nm}$.

\section{RESULTS AND DISCUSSION}

The isolated microalgal strain found to be a Dunaliella salina strain which was deposited in the microalgal culture collection of Shiraz University of Medical Sciences (MCCS). After reaching the mid stationary phase, the amount of $\beta$-carotene and glycerol at 1, 2, 8 and $24 \mathrm{~h}$ after initiating hypo-osmotic (1 M $\mathrm{NaCl})$ and hyper-osmotic shock $(3 \mathrm{M} \mathrm{NaCl})$; and at normal condition $(2 \mathrm{M} \mathrm{NaCl})$ was measured in three replicate and was shown in Fig.1 and Fig.2 respectively.

The data in fig. (1), revealed that the glycerol concentration after $1 \mathrm{~h}$ of salinity stress was $9.84 \pm 0.06$ (pg/cell) and reached the highest level after $24 \mathrm{~h}$ to $10.51 \pm 0.39$ (pg/cell), which was 2.27 folds relative to $1 \mathrm{M} \mathrm{NaCl}$ concentration $(4.63 \pm 0.51 \mathrm{pg} / \mathrm{cell})$. At the hypo-osmotic medium $(1 \mathrm{M} \mathrm{NaCl})$, the glycerol concentration after $1,2,8$ and $24 \mathrm{~h}$ was $4.77 \pm 0.565$; 
$4.75 \pm 0.530 ; 4.70 \pm 0.545$; and $4.63 \pm 0.510$, respectively. Increasing the glycerol content was in a close relation with elevation of salinity concentration. The maximum $\beta$-carotene concentration of $17.81 \pm 0.7 \mathrm{mg} / \mathrm{mL}$ was achieved after $24 \mathrm{~h}$ at $3 \mathrm{M} \mathrm{NaCl}$.

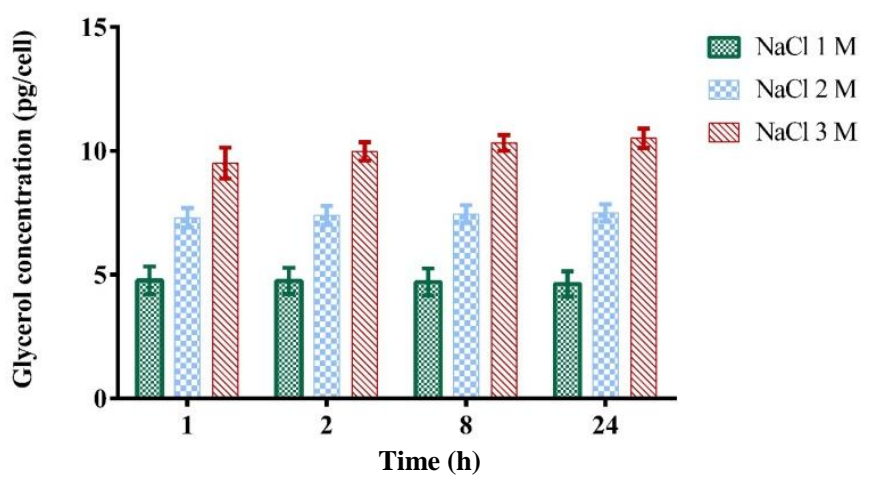

Fig. 1: Effects of osmotic shock on glycerol content using spectrophotometric method in $1 \mathrm{~h}$ to $24 \mathrm{~h}$ of experiment. The obtained values shown to be significantly different at the $p<0.005$ level.

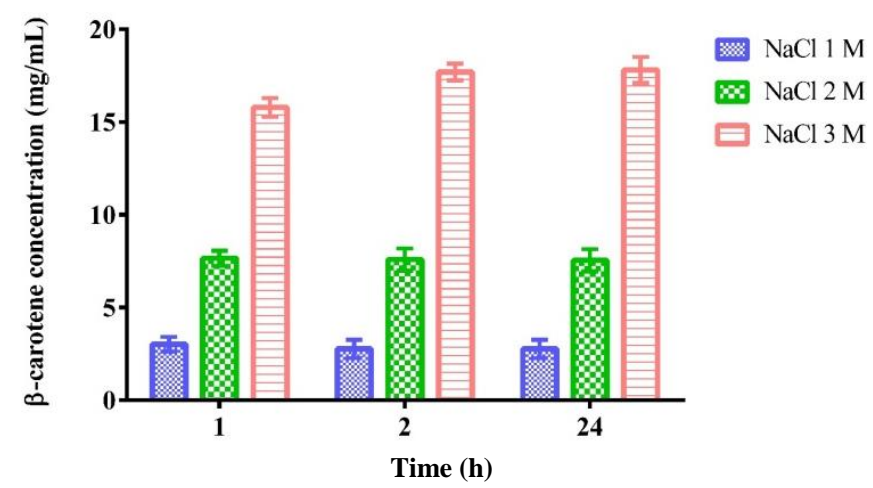

Fig. 2: Effects of osmotic shock on $\beta$-carotene content using spectrophotometric method in $1 \mathrm{~h}$ to $24 \mathrm{~h}$ of experiment. The obtained values shown to be significantly different at the $p<0.005$ level.

Under stress conditions, D. Salina could produce commercially important chemicals like glycerol and pigments (Chen et al., 2012, Fu et al., 2014 and Lamers et al., 2010). This ability is not similar in different isolated D. Salina strains from disparate locations around the world. Isolated strains from various geographical zones show different growth patterns, and this feature makes Dunaliella species unique in the ability of tolerating a wide range of salinities and producing valuable compounds, which is the cause of considerable attention to native strains of Dunaliella.

Glycerol synthesis within Dunaliella cells is directly related to the amount of salt outside the cells. As Zhao et al. (2013) mentioned, D. salina begins to synthesize glycerol in order to relieve the osmotic pressure approximately $1 \mathrm{~h}$ after salinity induction. They also reported that, after $24 \mathrm{~h}$, the cell was completely adapted to the salt stress from the external environment, and the intracellular glycerol content reached its highest levels. This observation was confirmed in the current study. When the salinity increased from $2 \mathrm{M}$ to $3 \mathrm{M}$, the glycerol content increased. This phenomenon occurs due to maintaining the generated osmotic pressure, which prevents the cells from bursting and death. As the results show, $24 \mathrm{~h}$ post salinity stress; glycerol concentration reached the maximum level, which is similar to previously reported results. On the other hand, when the salinity decreased from $2 \mathrm{M}$ to $1 \mathrm{M}$, the intracellular glycerol content decreased. Its probable reason is that, in hypo-osmotic situations, the produced glycerol within the cell is secreted out of the microalgal cell to balance the osmotic pressure between the inside and outside of Dunaliella cells.

Like glycerol concentration, $\beta$-carotene levels increase under stress conditions. As reported by Lamers et al. (2012) high light intensity and nitrogen deficiency affect $\beta$-carotene concentration in $D$. salina. In this study, we investigated the effects of low and high salt concentrations on $\beta$-carotene accumulation. $\beta$-carotene, as an antioxidant, protects photosynthetic cells against the oxidative stress. In addition, $\beta$ carotene captures light energy and transfers it to the chlorophylls. Extra-plastid lipid globules are locations used for $\beta$-carotene accumulation inside the cells. The formation and stabilization of these globules are associated with $\beta$-carotene accumulation. In the isolated strain of $D$. salina, $\beta$-carotene accumulation occurs in response to salinity stress and is closely related to the activity of carotene globule proteins (Cgp) (Katz et al., 1995).

As reported by Hadi et al. (2008), in Dunaliella salina isolated from the Gave-Khooni Salt Marsh in Iran, when salt concentration increases from $0.17 \mathrm{M}$ to $2 \mathrm{M}$, the total carotenoid concentration and carotenoid/chlorophyll ratio increases, which is in agreement with the results of our study. However, at higher salt concentrations $(\mathrm{NaCl} 3 \mathrm{M})$ total carotenoid decreases.

The data in fig. (2), when salt concentration increases from $2 \mathrm{M}$ to $3 \mathrm{M}, \beta$-carotene concentration increases. This means that $\beta$-carotene is the main carotenoid pigment necessary for protecting the cells against stress condition. $\beta$-carotene reached its maximum level after $24 \mathrm{~h}(17.81 \mathrm{mg} / \mathrm{mL})$ at $\mathrm{NaCl} 3 \mathrm{M}$. At hypoosmotic pressure, $\beta$-carotene concentration decreases and reached a constant value after $2 \mathrm{~h}$. It means that $D$. salina cells need $2 \mathrm{~h}$ to adapt to hypo-osmotic shock, and $\beta$-carotene is not a necessary pigment in D.salina cells in this condition. Under hyper-osmotic condition, $\beta$-carotene concentration reaches its maximum amount after $2 \mathrm{~h}$ and remains constant up to $24 \mathrm{~h}$. It reveals that $D$. salina cells adapt to a new condition by producing $\beta$-carotene after $2 \mathrm{~h}$. The results revealed that $\beta$-carotene and glycerol are the most important substances to protect Dunaliella cells against extreme conditions by different mechanisms. We also observed that increasing and decreasing the concentration of glycerol and $\beta$ carotene at hyper-osmotic and hypo-osmotic shock is completely independent and does not have any relation to each other and each of them play a unique role. According to the large number of lakes and salt marshes in Iran, there is a suitable climate for the growth of Dunaliella. So it seems that existing D.salina in different places in Iran is a potential microalga for planting in smaller locations to promote the commercial production of $\beta$-carotene and glycerol. 


\section{CONCLUSIONS}

The present work shows that osmotic shock can affect glycerol and $\beta$-carotene content in $D$. salina. In hyper-osmotic medium, glycerol and $\beta$-carotene concentrations were increased, but at hypo-osmotic medium the concentrations were decreased. Glycerol and $\beta$-carotene are critical compounds for $D$. salina at stress conditions. Native strains of $D$. salina according to their unknown potential ability are appropriate candidates for the industrial production of valuable biotechnological compounds.

\section{ACKNOWLEDGEMENTS}

This work was supported by a grant from the Research Council of Shiraz University of Medical Sciences, Shiraz University of Medical Sciences, Shiraz, Iran.

\section{REFERENCES}

Anderson R. Algal Culturing Techniques. Elsevier Academic Press, Burlington, USA. San Diego and London: Elsevier Academic Press; 2005.

Besson A, Guiraud P. High-pH-induced flocculation-flotation of the hypersaline microalga Dunaliella salina. Bioresource technology. 2013;147:464-70.

Chen H, Lao Y-M, Jiang J-G. Effects of salinities on the gene expression of a (NAD+)-dependent glycerol-3-phosphate dehydrogenase in Dunaliella salina. Sci. Total Environ., 2011;409(7):1291-7.

Chen H, Lu Y, Jiang JG. Comparative analysis on the key enzymes of the glycerol cycle metabolic pathway in Dunaliella salina under osmotic stresses. Plos One., 2012;7(6).

Chow YY, Goh SJ, Su Z, Ng DH, Lim CY, Lim NY, et al. Continual production of glycerol from carbon dioxide by Dunaliella tertiolecta. Bioresour. Technol., 2013;136:550-5.

De Santos Silva M, Ferreira PC. Glycerol: Production, structure and applications: Nova Science Publishers, Inc.; 2012. 1-305 p.

Eijckelhoff C, Dekker J. A routine method to determine the chlorophyll $a$, pheophytin $a$ and $\beta$-carotene contents of isolated photosystem II reaction center complexes. Photosynth. Res., 1997;52(1):69-73.

Fu W, Paglia G, Magnusdottir M, Steinarsdottir EA, Gudmundsson S, Palsson BO, et al. Effects of abiotic stressors on lutein production in the green microalga Dunaliella salina. Microb. Cell Fact., 2014;13:3.

Ghasemi Y, Faramarzi MA, Arjmand-Inalou M, Mohagheghzadeh A, Shokravi S, Morowvat MH. Side-chain cleavage and C-20 ketone reduction of hydrocortisone by a natural isolate of Chroococcus dispersus. Ann. Microbiol., 2007;57(4):577-81.

Ghasemi Y, Rasoul-Amini S, Morowvat MH, Azam SBM, Shokravi S, Mohagheghzadeh A, et al. Bioconversion of hydrocortisone by unicellular microalga Oocystis pusilla. Biotechnology., 2008a;7(2):293-8.

Ghasemi Y, Rasoul-Amini S, Morowvat MH, Raee MJ, Ghoshoon MB, Nouri F, et al. Characterization of hydrocortisone biometabolites and 18S rRNA gene in Chlamydomonas reinhardtii cultures. Molecules., 2008b;13(10):2416-25.

Ghasemi Y, Rasoul-Amini S, Morowvat MH. Algae for the production of SCP. Bioprocess Sciences and Technology: Nova Science Publishers, Inc.; 2011a. p. 163-84.

Ghasemi Y, Rasoul-Amini S, Kazemi A, Zarrinic G, Morowvat MH, Kargar M. Isolation and characterization of some moderately halophilic bacteria with lipase activity. Mikrobiologiia., 2011b;80(4):47781.

Hadi MR, Shariati M, Afsharzadeh S. Microalgal biotechnology: Carotenoid and glycerol production by the green algae
Dunaliella isolated from the Gave-Khooni salt marsh, Iran. Biotechnol. Bioproc. Eng., 2008;13(5):540-4.

Hosseini Tafreshi A, Shariati M. Dunaliella biotechnology: Methods and applications. J. Appl. Microbiol., 2009;107(1):14-35.

Katz A, Jimenez C, Pick U. Isolation and characterization of a protein associated with carotene globules in the alga Dunaliella bardawil. Plant Physiol., 1995;108(4):1657-64.

Lamers PP, Janssen M, De Vos RC, Bino RJ, Wijffels RH. Carotenoid and fatty acid metabolism in nitrogen-starved Dunaliella salina, a unicellular green microalga. J. Biotechnol., 2012;162(1):21-7.

Lamers PP, Van De Laak CCW, Kaasenbrood PS, Lorier J, Janssen M, De Vos RCH, et al. Carotenoid and fatty acid metabolism in light-stressed Dunaliella salina. Biotechnol. Bioeng., 2010;106(4):638-48.

Lee S-Y, Kim S-H, Hyun S-H, Suh HW, Hong S-J, Cho B-K, et al. Fatty acids and global metabolites profiling of Dunaliella tertiolecta by shifting culture conditions to nitrate deficiency and high light at different growth phases. Process Biochem., 2014;49(6):996-1004.

Lers A, Biener Y, Zamir A. Photoinduction of massive $\beta$ carotene accumulation by the alga Dunaliella bardawil: Kinetics and dependence on gene activation. Plant Physiol., 1990;93(2):389-95.

Mishra A, Jha B. Isolation and characterization of extracellular polymeric substances from micro-algae Dunaliella salinaunder salt stress. Bioresour. Technol., 2009;100(13):3382-6.

Mojaat M, Foucault A, Pruvost J, Legrand J. Optimal selection of organic solvents for biocompatible extraction of beta-carotene fromDunaliella salina. J. Biotechnol., 2008;133(4):433-41.

Nasseri AT, Rasoul-Amini S, Morowvat MH, Ghasemi Y. Single cell protein: Production and process. Am. J. Food Technol., 2011;6(2):103-16.

Powtongsook S, Kittakoop P, Menasveta P, Wisessang S. Isolation and characterization of Dunaliella salina from Thailand. J. Appl. Phycol., 1995;7(1):75-6.

Rasoul-Amini S, Ghasemi Y, Morowvat MH, Ghoshoon MB, Raee MJ, Mosavi-Azam SB, et al. Characterization of hydrocortisone bioconversion and 16S RNA gene in Synechococcus nidulans cultures. Appl. Biochem. Microbiol., 2010;46(2):191-7.

Rodriguez GA. Extraction, isolation, and purification of carotenoids. Current Protocols in Food Analytical Chemistry: John Wiley \& Sons, Inc.; 2001.

Saha SK, Moane S, Murray P. Effect of macro- and micronutrient limitation on superoxide dismutase activities and carotenoid levels in microalga Dunaliella salina CCAP 19/18. Bioresour. Technol., 2013;147:23-8.

Wang Z, Zhuge J, Fang H, Prior BA. Glycerol production by microbial fermentation: A review. Biotechnol. Adv., 2001;19(3):201-23.

Xiao Y, Xiao G, Varma A. A universal procedure for crude glycerol purification from different feedstocks in biodiesel production: Experimental and simulation study. Ind. Eng. Chem. Res., 2013;52(39):14291-6.

Yazdi MT, Ghasemi Y, Ghasemian A, Shokravi S, Niknahad H, Amini M, et al. Bioconversion of hydrocortisone by cyanobacterium Fischerella ambigua PTCC 1635. World J. Microbiol. Biotechnol., 2005;21(6-7):811-4

Yuan W, Li H. The applications of glycerol in pharmaceutical formulation. Glycerol: Production, Structure and Applications: Nova Science Publishers, Inc.; 2012. p. 287-91.

Zhao L-n, Gong W-f, Chen X-w, Chen D-f. Characterization of genes and enzymes in Dunaliella salina involved in glycerol metabolism in response to salt changes. Phycol. Res., 2013;61(1):37-45.

\section{How to cite this article:}

Nima Montazeri-Najafabady, Manica Negahdaripour, Mohammad Hossein Salehi, Mohammad Hossein Morowvat, Younes Ghasemi. Effects of osmotic shock on production of $\beta$-carotene and glycerol in a naturally isolated strain of Dunaliella salina. J App Pharm Sci, 2016; 6 (08): 160-163. 